\title{
Views of Science and Mathematics Pre-service Teachers Regarding STEM
}

\author{
Sinan Cinar, Nimet Pirasa, Gunay Palic Sadoglu* \\ Faculty of Education, Recep Tayyip Erdogan University, Turkey
}

Copyright $\bigcirc 2016$ by authors, all rights reserved. Authors agree that this article remains permanently open access under the terms of the Creative Commons Attribution License 4.0 International License

\begin{abstract}
STEM education is an integrated approach that combines science, technology, engineering and mathematics disciplines with different subjects in real life situations, together and simultaneously. The views of pre-service teachers introduced to STEM by means of workshops that presented information and scales on STEM education regarding the subject were collected in this study. The participants of the study were the senior class students at the Recep Tayyip Erdogan University, Faculty of Education, Department of Primary Education, Physical Sciences (37 members) and Mathematics Education (20 members). A survey with open-ended questions was used to collect data. A descriptive content analysis was performed and the data were summarized in the tables. The results showed that the pre-service teachers have more positive views about the STEM approach, and there is not a significant difference between the views of science and mathematics teachers. Also, they reported positive views about making such applications in their future classes.
\end{abstract}

Keywords STEM Education, The Pre-service Teachers of Science and Mathematics, Pre-service Training

\section{Introduction}

STEM (Science, Technology, Engineering and Mathematics) education, one of the significant developments in the education of twenty first century, is an approach that combines engineering and mathematics content and skills [2, $5,15,19,25]$. STEM was first introduced by the American National Science Foundation (NSF) as the combination of science, technology, engineering and mathematics [23, 28]. STEM is an integrated approach, teaching science, technology, engineering and mathematics disciplines with different subjects in real life situations, together and simultaneously [17]. STEM education allows students to understand the world as a whole rather than in parts and eliminates the impediments present between science, technology, engineering and mathematics disciplines by integrating a combined learning and teaching approach [20]. Thus, STEM education emphasizes the synthesis of knowledge among these four disciplines and possesses integrating properties [18].

Due to the fast economic, social, scientific and technological developments of our age, students need to be raised as individuals with twenty first century skills such as creative and innovative, critical thinking, problem solving, decision making skills as well acknowledge about scientific reading-writing, life and career, and sense of responsibility. The twenty first century skills and competencies are quite an endeavor for any educational system. It involves not only a continuous change in decision-making, but also the society as a whole has to care about the future of children, and provide what is necessary to help them to achieve their own personal goals, empowering and nurturing them from their early years as autonomous citizens who will have the self-confidence to create their own future [27].However, this does not seem possible with a science education that teaches only the basic concepts. In other words, skills like creativity, critical thinking, problem solving and collaborative working skills cannot be acquired to students with the classical education approach [29]. Therefore, application of new approaches and practices in education institutions becomes a necessity [22]. It is intended to educate students in an integrated way and allow them to gain twenty first century skills through the STEM education. In this regard, science, technology, engineering and mathematics disciplines play a significant role in developing these twenty first century skills $[1,4,24]$. Gaining these skills is also important for making decisions in social, economic and political issues [24].It is noted that students trained with STEM education grow up to be problem solver, innovative, self-confident, logically thinker, science and technology author-reader individuals and those STEM programs using information technologies contribute the development of critical thinking skills of students [16]. However, students lacking STEM skills could not head towards science and engineering related professions or disciplines that require literacy in mathematics, science and technology [7].

Moreover, STEM education bears a strategic importance 
for Turkey to sustain its international competitive power and therefore, innovations in the field of STEM have become critical for the country's economic competitiveness [11]. Our country requires highly qualified STEM work power in order to increase its innovative capacity. That's why our young generation needs to be brought up from early age with the ability to perform natural sciences, engineering and technology researches. In this respect, STEM related studies will make a contribution specifically to science, technology, mathematics and engineering education and to the country's economy and development in general. Thus, they will lead the country to be one of the developed states [21].

Organisation for Economic Co-operation and Development [OECD] (2009) data show that according to the views of school principals, quantitative deficiency in qualified teachers is high in Turkey, which impedes primary education [13], and there is an intense criticism about the teachers, who are expected to educate the work power that will specialize in STEM fields, are not educated enough as required by our age [11]. Corlu and Corlu [13] (2012) determined in their study that pre-service teachers educated in the field of physics have difficulties in transferring and correlating the mathematics formulation to measuring and evaluation processes. Pre-service teachers need to develop their basic mathematics skills and the importance of a strong knowledge of mathematical process and concept required to become successful in science based on academic questioning is revealed [10]. It is indicated that teachers possessing teaching knowledge only in their fields of specialization will not be sufficient to bring up the human power required by our country [11]. However, a STEM teacher possesses other knowledge from the field of STEM in addition to their field of specialization. This improved knowledge gives the teacher an effective STEM practitioner competence in both the field and field education. That is why characteristics of STEM teachers and education of field teachers is of critical importance for our country [9]. In this regard, it is suggested to increase the STEM teaching skills of teachers and pre-service teachers by means of in-service training. Also, during the education given in faculties, to diversify and enrich teacher training by ensuring collaboration of the education faculties of universities with such faculties as engineering and science, pre-service teachers should be provided with the necessary knowledge and skills practicing STEM education [29].

In order for Turkey to achieve the miracle created in Asia by Japan in 1980s and by South Korea in 2000s, it is required to train an innovative, entrepreneur, creatively thinking generation that is interested in STEM fields [29]. It is noted that we need an education culture that will give students responsibility, promote their thinking, provide them with technological knowledge such as computer programming from early ages, and encourage them to become entrepreneurs. Besides, it is concluded that Turkey will be unable to compete in the field of economy in the $21^{\text {st }}$ century without creating such education culture and without bringing up a generation able to apply knowledge and skills in the science, mathematics, engineering, computer disciplines. Thus, STEM education becomes a necessity for Turkey, but presenting such education to students is not easy; hence, education policies and programs need to be improved with the consideration of the country's needs. As it can be seen, the importance of STEM education is increasing progressively and Turkey needs to take serious steps about STEM education [29].

While multiple studies on STEM education are being conducted in the United States of America, only a limited number of studies have been performed in Turkey. Corlu [9] (2014) provides researchers likely to contribute to our knowledge repertoire in the field of STEM education with design and method suggestions and encourages researchers to publish the results of their STEM education studies. Corlu, Caparo and Caparo [11] (2014) aimed to identify STEM education in their research within the scope of theories. Integrated curriculum, studies performed in the field of teaching knowledge in Turkey and in the world, and ongoing education reform initiatives were examined for this purpose. When focusing on the interaction between science and mathematics, which is an outcome of the conceptualized model, it was concluded that teachers possessing only teaching knowledge in their field of specialization will not be sufficient to train the human power required by our country. Yamak, Bulut and Dundar [30] (2014) discussion their research the effect of Science-Technology-Engineering and Mathematics activities on the academic process skills and attitudes towards science among secondary school $5^{\text {th }}$ grade students. By the end of the study, it was concluded that STEM activities affect the academic process skills and attitude towards science among students in a positive manner. Ceylan [7] (2014) examined during his study the effect of teaching model prepared on the basis of Science, Technology, Engineering and Mathematics (STEM) education in relation to the Acids and Alkalis subject for the secondary school $8^{\text {th }}$ grade physical sciences class on the academic success, creativity and problem solving skills of students, and then, compared it to the application of constructivist approach supported by training practices based on the current physical sciences education program for the same subject, and determined the views of students on the STEM education. At the end of the study, it was found that the academic success, creativity and problem solving skills of students from the experiment group were higher than those of the students from the control group. In addition, it was reported that views of students from the experiment group regarding the subject training model prepared on the basis of STEM education were positive in general. Marulcu and Hobek [21] (2014) studied an experimental study to evaluate the effect of a sample activity plan prepared in relation to alternative energy sources in compliance with the engineering design approach on the successfulness of $8^{\text {th }}$ grade students in two village schools located in one of the southern regions. Experiment group was subject to application of activities designed using the engineering design method in relation to the alternative energy sources 
subject, while the control group performed activities from the current course books as approved by the Ministry of National Education [22] on the same subject. 9688 Renewable Energy sets manufactured by the Lego Education Company during the Alternative Energy Sources related activity application in the experiment classes. Additionally, example activities presented in the instructions for the set were used when preparing lesson plans. At the end of the study, the experiment group was more successful. Corlu [14] (2013) aimed to delineate the teaching practices in science, technology, engineering, and mathematics at the postsecondary level through an assessment of course syllabi. An analytical rubric was developed with the STEM community, STEM education, and STEM assessment factors in order to assess teaching practices through syllabi of the courses offered at a public university within the European Higher Education Area. Results in study showed that there were statistically significant differences between the externally accredited and non-accredited programs in STEM education and STEM assessment variables, which indicated a practical significance in favor of accredited programs. At the end of his study, he concluded that the ABET (Accreditation Board for Engineering and Technology) accreditation program will play a supportive role in application of teaching methods appropriate for the STEM education by developing internal audit mechanisms and compliance with the European Higher Education Universities Bologna Process. Corlu, Capraro and Capraro [12] (2015) stated that pre-service teachers in Turkey are not educated as required by the age; therefore, teacher training programs are receiving criticism. The study was intended to determine the cognitive readiness for combined science and mathematics among 226 science and mathematics pre-service teachers receiving education in two different universities in Turkey (one implements a combined teacher training program and the other implements non-combined training program). At the end of the study, it was determined that pre-service mathematics teachers within the combined education program had a more positive attitude than pre-service mathematics teachers trained within a non-combined education program. The study indicates that a combined curriculum would be an effective alternative to the teacher training programs in Turkey and that combined science and mathematics curriculum would allow pre-service teachers to develop a more positive attitude towards the science and mathematics education.

When the studies conducted in Turkey in relation to the STEM education are compared to other countries, it is seen that they are in limited numbers, which shows the necessity of new studies in this field. Therefore, increasing collaboration among mathematics, physical sciences and technology-design teachers in our schools, developing STEM education models on the basis of research to ensure support for the development of critical and creative thinking skills among students, preparation of professional development materials in relation to STEM education adopted to Turkey's conditions, testing of such materials and publishing of results by means of academic magazines and conferences is necessary [9]. In this regard, the current study is intended to contribute to the related field literature by collecting the views of pre-service teachers introduced to STEM by means of workshop that presented information and scales on STEM education regarding the subject.

\section{Method}

The participants of the study were the senior class students receiving training at the Recep Tayyip Erdogan University, Faculty of Education, Department of Primary Education, Physical Sciences (37members) and Mathematics Education (20 members). The study was conducted during the last month of their last academic year because the study especially preferred pre-service teachers at the stage of graduation from the faculty of education, who received the necessary knowledge to become teachers. 57 students are determined to constitute the study group from 72 pre-service teachers who had participated to the study, but the rest of them did not answer all of the questions of the questionnaire. The characteristics of pre-service teachers participating in the study are listed below in Table 1 .

Table 1. Demographic characteristics of participants

\begin{tabular}{|c|c|c|c|}
\hline \multicolumn{2}{|c|}{ Demographic characteristics of participants } & $\mathrm{f}$ & $\%$ \\
\hline \multirow{2}{*}{ Field } & $\begin{array}{c}\text { Physical } \\
\text { Sciences }\end{array}$ & 37 & 65 \\
\cline { 2 - 4 } & Math & 20 & 35 \\
\hline Sex & Female & 41 & 72 \\
\cline { 2 - 4 } & Male & 16 & 28 \\
\hline $\begin{array}{c}\text { Heard about STEM education } \\
\text { before participating in this } \\
\text { study }\end{array}$ & Yes & 2 & 4 \\
\cline { 2 - 4 } & No & 55 & 96 \\
\hline
\end{tabular}

\subsection{Application Period}

In the beginning of the application period, senior students from the department of natural sciences education and mathematics education of the faculty of education were presented a seminar on STEM. The seminar was conducted by the Kayseri Regional National Education Directorate STEM team, which implements the STEM Education for the first time in Turkey in Kayseri as a pilot region. Workshops were conducted with 72 volunteers from the students participating in the seminar that consisted on total of 12 groups.

The applications were conducted in two days with 6 workshops that each of them took 2 hours. During the 3 workshops conducted on the first day, mechanical designs such as mechanical car, winding wheel, balloon car, and scissor elevator were made. During the second day, before workshops, the participants received training on the Robo-PRO software, where they could create their own software. During the workshops conducted later on, models of traffic lights, solar helicopter, solar car and hand dryer 
were made. At the workshops just a mere model design is dealt with and no association with the teaching program is performed.

\subsection{Data Collection and Analysis}

A survey with open ended questions was used as the data collection tool to take the participants views about STEM and STEM application. The views of pre-service teachers regarding each day of the two-day seminar were collected. First a draft survey developed for the relevant of the study purpose by the researchers of this study who specialized the subject of STEM. After examining the draft survey, a pilot study was conducted to 5 students at same characteristics of this study participant about the comprehensibleness of the questions and the application time to answer the questions on the main study. Based on the feedback received from the pilot study, the last version form of the survey was given to perform on the main study. The survey implemented during the first day included 3 questions that allowed pre-service teachers to make a general evaluation of the workshops conducted during that day. The survey implemented during the second day, in addition to the questions allowing pre-service teachers to make general evaluation of the workshops conducted during that day, 7 questions that allowed for evaluation of STEM and the overall workshops were included. The data collected from the survey were supported by the observations from field notes taken by the researchers during the application.

A descriptive content analysis was performed with the codes obtained from the data were converted into the themes. Firstly after gathering information through the survey, verbatim transcription of the questions made, the data were coded to find themes focusing on the research problems. To minimize the possible bias in coding and data reduction, two experts (two researcher of this study who experienced in qualitative research) were coded the data in dependently and then compared with each other.

In this process in order to check the interrater reliability of the two experts, the transcribed data and the codes emerged were analyzed and calculated to find the Kappa coefficient. In this case as there are two raters, instead of Cohen Kappa, Fleiss Cappa coefficient is calculated and it was 0.73 which indicated agreement at a significant level. After the coding process, the third researcher of this study was also involved to check the last version of the final coding list, and the themes emerged from the whole set of data to validate from the theoretical aspect. At last the themes and codes were summarized in the Table 2, Table 3, Table 4, Table 5, Table 6 and Table 7 in the results of the study.

While reporting the results, the selected quotations which were chosen according to their relevance with the research questions, and being explanatory to explain the codes from a rich descriptive perspective. Providing detailed information about the participants may result in revealing the identities of the participants so nick names were used in the study like [PT1, science], [PT1, math] (the number of pre-service teacher and their department).

\section{Results}

The views of the pre-service teachers are handled with four categories: STEM, the contribution of STEM to the student, the applicability of STEM and its professional development aspects.

\subsection{Views Regarding STEM}

Pre-service teachers' views on STEM are determined and summarized in the Table 2 below.

Table 2. Views related to STEM

\begin{tabular}{|c|c|c|}
\hline Themes & Codes & Frequency \\
\hline \multirow{3}{*}{ Affective Aspect } & Is enjoyable & 12 \\
\hline & Is interesting & 4 \\
\hline & Arouses curiosity & 2 \\
\hline \multirow{3}{*}{ Cognitive Aspect } & Improves spatial skills & 10 \\
\hline & Enforces the student to think & 5 \\
\hline & Strengthens the visual memory & 3 \\
\hline \multirow{3}{*}{$\begin{array}{l}\text { Psychomotor } \\
\text { Aspect }\end{array}$} & Develops the psychomotor skills & 9 \\
\hline & Product is generated & 7 \\
\hline & Projects can be developed & 4 \\
\hline \multirow{7}{*}{ Learning Process } & $\begin{array}{c}\text { Incentivizes collaborative } \\
\text { working }\end{array}$ & 34 \\
\hline & Social interaction is realized & 20 \\
\hline & $\begin{array}{c}\text { Ensures effective and permanent } \\
\text { learning }\end{array}$ & 19 \\
\hline & Requires systematic working & 9 \\
\hline & Conceptual learning is realized & 4 \\
\hline & $\begin{array}{c}\text { Helps to associate the subject with } \\
\text { daily life }\end{array}$ & 1 \\
\hline & Provides concrete experience & 1 \\
\hline \multirow{4}{*}{$\begin{array}{l}\text { Interdisciplinary } \\
\text { Interaction }\end{array}$} & Is science oriented & 27 \\
\hline & Is applicable for mathematics & 13 \\
\hline & Is integrated & 7 \\
\hline & Is applicable for technology & 4 \\
\hline
\end{tabular}

The views of the pre-service teachers about STEM is that it is enjoyable to apply, develops the spatial and psychomotor skills of the student, that it incentivizes collaborative learning, realizes social interaction, ensures effective and permanent learning and is science oriented. The view related to STEM that it is science oriented contradicts with that STEM is an interdisciplinary approach. When the views are examined, it is seen that the science pre-service teachers do not feel the necessity to find any samples regarding the other disciplines and that nearly all of the mathematics pre-service teachers interrogate its applicability for mathematics and tried to give sample related to mathematics subjects with regards to this. The look of the structures, geometric objects, patterns and decorations, 
rotation movements and problems are samples provided on this issue. This might be due to the fact that only the description of the STEM set is taken into consideration at the workshop. It is understood from the samples that some of the pre-service teachers, even if a little number, are aware of that STEM is an integrating teaching approach: "...we can use the balloon car we made and adapt this to speed questions based on the air amount inside the balloon. Calculations may be performed with regards to the questions on how the car got, how it could move longer or how else it could move." [PT4, maths]; “...Incredible things will develop in human life when science, technology, engineering and mathematics are combined." [PT18, science].

Beside this, when the views regarding the STEM application are examined, it can be seen that they have used attributes like "a brain improving application", "a good activity that they like coming to school", "an efficient game like puzzle", "a work which makes one deal with it until the solution at an addiction level". These statements are such to support their positive views on STEM.

\subsection{Views on the Contribution of STEM to the Student}

Primarily, the views of the pre-service teachers with regard to the contribution of STEM to the formation of the future of the students' and its suitability for children of any age are obtained. (Table 3 ).

Table 3. Views about the belief of the contribution of STEM to the student

\begin{tabular}{|c|c|c|}
\hline Question & Response & Frequency \\
\hline \multirow{3}{*}{$\begin{array}{l}\text { Do you think that the STEM education } \\
\text { and teaching applications will contribute } \\
\text { to the formation of the future of the } \\
\text { students? }\end{array}$} & Yes & 44 \\
\hline & No & 2 \\
\hline & $\begin{array}{c}\text { No } \\
\text { expression }\end{array}$ & 11 \\
\hline \multirow{3}{*}{ Is STEM suitable for children of any age? } & Yes & 30 \\
\hline & No & 3 \\
\hline & $\begin{array}{c}\text { No } \\
\text { expression }\end{array}$ & 24 \\
\hline
\end{tabular}

All the participants (except 2 of them) declared that STEM has contributions to student. Moreover 30 of the participants expressed that STEM is convenient for children of any age although 24 of them stated no expression.

Then their views on how far STEM would contribute to the students are determined and summarized in the Table 4 below.

Table 4. Views related to the contribution of STEM to the student

\begin{tabular}{|c|c|c|}
\hline Themes & $\begin{array}{c}\text { Codes } \\
\end{array}$ & Frequency \\
\hline \multirow{8}{*}{ Affective development } & Increases the success related to the course & 15 \\
\hline & Improve the positive attitude towards the course & 13 \\
\hline & Increases the sociality & 11 \\
\hline & Increases the confidence with regards to the course & 9 \\
\hline & Attracts his/her interest for the course & 9 \\
\hline & Increases the motivation with regards to the course & 8 \\
\hline & Perceives the funny aspects of the course & 8 \\
\hline & Experiences the feeling of success & 8 \\
\hline \multirow{13}{*}{ Cognitive development } & Directs to thinking & 24 \\
\hline & Improves the creativity & 19 \\
\hline & Contributes to the mental development & 14 \\
\hline & Develops rapid thinking skills & 10 \\
\hline & Develops practical thinking skills & 9 \\
\hline & Ensures thinking in multiple perspectives & 8 \\
\hline & Develops the problem solving skill & 7 \\
\hline & Develops the communication skill & 7 \\
\hline & Develops the imagination & 5 \\
\hline & Ensure critical thinking & 4 \\
\hline & Develops the abstract thinking skills & 3 \\
\hline & Develops the association skills & 2 \\
\hline & Develops the sense for aesthetic & 1 \\
\hline \multirow{3}{*}{ Psychomotor development } & Develops the psychomotor skills & 26 \\
\hline & Generates a product & 9 \\
\hline & Improves the usage of technology & 4 \\
\hline \multirow{6}{*}{ Learning process } & Ensures learning by doing, experiencing & 26 \\
\hline & Helps to concretize the subjects & 22 \\
\hline & Takes active role at group works & 16 \\
\hline & Associates the subject with daily life & 8 \\
\hline & Uses the subject in daily life & 5 \\
\hline & Develops observing skills & 4 \\
\hline \multirow{5}{*}{$\begin{array}{l}\text { Career guidance (contribution to } \\
\text { future) }\end{array}$} & Contributes to the profession selection & 19 \\
\hline & Forms his/her future & 13 \\
\hline & Gains a scientific perspective & 9 \\
\hline & Develops engineering skills & 8 \\
\hline & Ensures the growth of specialists in their field & 5 \\
\hline
\end{tabular}


The views regarding the contribution of STEM to the student expressed mostly by the pre-service teachers are that it increases the success in the course, the students develop a positive attitude with regard to the course, increases the sociality, directs to thinking, develops their creativity, contributes to the mental development, develops their psychomotor skills, contributes to the profession selection and directs the future. Also, they learn by doing and experiencing and they take an active role at group works. The striking statement of the pre-service teachers summarizes these views: "We have an education system where things are memorized and forgotten in a short time. We need to learn by doing in order to overcome this. With this application we teach our students the thinking structure of a little engineer or a scientist. Their abstract thinking abilities are progressing. Their problem solving, reasoning, associating skills develop. We need this application if we want to teach mathematics. We need this application if we want engineers, scientists and a good education system." [PT10, math]; "The application is very beneficiary since the provision of the group unity, the happiness of being able to succeed and confidence creates the "I can" awareness for the student and ensures that they learn to generate products with joy, fun and the spirit of sharing without being trapped by theoretical knowledge within the class." [PT47, science]. Also some of them drew attention to the psychomotor ability of people's: "the average of my friends is 19-25 years old. Most of them don't know how to replace a bulb. I suppose it is clear why we need this application." [PT50, math]; "Many engineers meet machines etc. for the first time at universities. This education will ensure the increase of the interest for these fields, the quality."[PT57, science]. PT45(science) emphasis making the life easier with this speech: "Understanding life is facilitated. The individual can solve it himself in case of a problem during daily life".

\subsection{Applicability of STEM}

The views of the pre-service teachers with regard to the applicability of STEM are indicated in the Table 5 below.

Whilst more than the half of the pre-service teachers attracted the attention on the supply of sufficient materials, the remaining nearly half have emphasized on the time management and the definition directives of the STEM methods. The view like "Individual working possibilities should be provided" constitutes a contradiction to the view "It would incentive the collaborative working" expressed by more than the half of pre-service teachers (see Table 4). This indicates that the pre-service teachers like individual working and experience a problem at collaborative working. It is understood in this aspect that the groups need to be organized well. On the other side, only one person has expressed that the nature of the STEM approach should be "free activity": "I wish the works were conducted without being bound to a paper. It would be much more joyful when we could develop a strategy and develop our own strategy in order to solve it by our own."[PT19, science]. But more than one fourth of the pre-service teachers who indicated on the dependency to the regulations have expressed the view that "STEM set definition directives should be open". It is understood that the candidates couldn't set a distance to the traditional life they grew in while trying to learn modern approaches.

Table 6. Views related to the applicability of STEM

\begin{tabular}{cc}
\hline Codes & Frequency \\
\hline $\begin{array}{c}\text { Sufficient material supply } \\
\text { Time management (the time should be used efficiently) } \\
\text { The introduction directives of the STEM set should be } \\
\text { Need for guidance }\end{array}$ & 25 \\
$\begin{array}{c}\text { the application } \\
\text { The inclusion of multiple activities }\end{array}$ & 9 \\
A follow-up from simple to difficult should be tracked at & 8 \\
There should be space for individual activities & 7 \\
The number of the groups should not be many & 7 \\
It should be worked with smaller workgroups & 3 \\
There should be space for free activities & 3
\end{tabular}

\subsection{Views Regarding the Professional Development}

The pre-service teachers are primarily asked what they think on applying the STEM while obtaining their views about their professional development (Table 6).

Table 7. Views about the beliefs on applying STEM in their courses

\begin{tabular}{ccc}
\hline Question & Response & Frequency \\
\hline & Yes & 55 \\
Will you use STEM in your & No & - \\
professional life? & No & 2 \\
& expression & 2 \\
\hline
\end{tabular}

Almost all of the pre-service teachers think of applying the STEM in their courses. Then they are asked how much they will use STEM in their courses. The views of the pre-service teachers regarding the professional development are indicated in the Table 7 below: 
Table 8. Views regarding the professional development

\begin{tabular}{lcc}
\hline Themes & Codes & Frequency \\
\hline & I apply it as a project based learning activity & 5 \\
I apply it along with the show and implement method & 4 \\
I use it during the application of activities or experiments & 6 \\
$\begin{array}{l}\text { Method of the application } \\
\text { of the STEM method during } \\
\text { the course }\end{array}$ & I apply it at issues hard to understand & 2 \\
& I use it as a problem solving activity & 2 \\
& I use it as a game & 2 \\
& I apply it at the consolidation of the subject & 1 \\
& I apply it directly for the explanation of the subject & 1 \\
& In activities except the course & 1 \\
\hline $\begin{array}{c}\text { Course-extern STEM } \\
\text { application }\end{array}$ & In free-time activities & 3 \\
& During optional courses & 3 \\
\hline $\begin{array}{l}\text { Contribution to the } \\
\text { professional development }\end{array}$ & I got aware of the importance of collaborative working & 1 \\
\hline
\end{tabular}

As it can be seen from the table, the pre-service teachers have indicated that they plan to apply the STEM as a course-external activity and free-time activity whilst they will apply a project based learning activity during the course. Beside this, when we examine the table, we see that the frequency figures are very low. The pre-service teachers weren't able to associate these with the teaching programs though the model designs during the workshop. This might be resulted from their idea how they should include STEM was not clear.

\section{Discussions and Conclusion}

The purpose of the current study is to determine the views of pre-service teachers introduced to STEM by means of workshop that provided information and presented models on STEM education in this study. In this context the views of the pre-service teachers are handled with four categories: STEM, contribution of STEM to the student, the applicability of STEM and its professional development aspects.

At the end of the workshop the pre-service teachers possess positive views with regard to STEM that it is funny to apply, develops the spatial and psychomotor skills of the student, that it incentivizes collaborative learning, realizes social interaction, ensures effective and permanent learning. Besides all these, pre-service teachers stated that STEM is science oriented, even though the science pre-service teachers did not feel the necessity to find any samples regarding the other disciplines except for science. However, STEM was an interdisciplinary approach [17]. This might be due to the fact that only the description of the STEM set is taken into consideration at the workshop. Generally four disciplines of STEM education combined to teach a science subject were used in the studies [8]. It is needed new studies about the combination of disciplines to teach other disciplines except for science. The mathematics pre-service teachers' behavior about interrogating STEM's applicability for mathematics and trying to give sample related to mathematics subjects indicates this requirement.

On the other hand pre-service teachers emphasized the attention on the supply of sufficient materials, time management and the definition directives of the STEM methods about STEM workshop. Although many of the pre-service teachers expressed STEM would incentivize the collaborative working, some of the pre-service teachers who had a problem with collaborative working in the workshop stated that individual working possibilities should be provided in the activities. This emphasized the importance of the well-organized groups.

Another result revealed that nearly all of the pre-service teachers were declared that STEM has contributions to students and half of them expressed that STEM was convenient for children of any age. The views regarding the contribution of STEM to the student expressed mostly by the pre-service teachers are that it increases the success in the course, the students develop a positive attitude with regard to the course, increases the sociality, directs to thinking, develops their creativity, contributes to the mental development, develops their psychomotor skills, contributes to the profession selection and directs the future. Also, they learn by doing and experiencing and they take an active role at group works. Similar results were obtained from the previous researches' results. Yamak et al. [30] (2014) stated that students who had STEM education had positive attitudes towards science. Besides, Bicer et al. [3] (2015) STEM practices give students opportunity of working collaboratively, meaningful learning through hands on activities, and developing students' conceptual and 
procedural understanding. Moreover, Sahin et al. [26] (2014) emphasized that STEM developed and practiced students' communication and collaboration skills and creativity for lifelong learning. STEM provided with the opportunity to acquire problem-solving skills and experience that students might encounter in their daily lives.

Pre-service teachers think of applying the STEM in their courses. They planned to apply the STEM as a course-external activity and free-time activity whilst they will apply a project based learning activity during the course. Similar STEM practices can be seen in the literature conducted on project based learning, problem based learning or inquiry based learning as well as course-external or free-time activities [3, 6, 7, 19, 21].In addition, the pre-service teachers were not able to associate these with the teaching programs though the model designs during the workshop. This might be resulted from their idea how they should include STEM was not clear.

To conclude, pre-service teachers have more positive views about the STEM approach, and there are not significant differences between the views of science and mathematics teachers. Also, they reported positive views about making such applications in their future classes.

\section{REFERENCES}

[1] Becker, K. \& Park, K. (2011). Effects of integrative approaches among science, technology, engineering, and mathematics (STEM) subjects on students' learning: a preliminary meta-analysis. Journal of STEM Education, 12(5), 23-37.

[2] Berlin, D. \& Lee, H. (2005). Integrating science and mathematics education: Historical analysis. School Science and Mathematics, 105(1), 15-24.

[3] Bicer, A., Navruz, B., Capraro, R., Capraro, M.M., Oner, T. \& Boedeker, P. (2015). STEM Schools vs. Non-Stem Schools: Comparing Students' Mathematics Growth Rate on High-Stakes Test Performance, International Journal on New Trends in Education and Their Implications, 6(1): 1309-6249

[4] Bybee, R.W. (2010). Advancing STEM Education: A 2020 Vision. Technology and Engineering Teacher, 70 (1), 30-35.

[5] Cavanagh, S. \& Trotter, A. (2008). Where's the "T" in STEM? Education Week, 27(30), 17-19. Retrieved June 1, 2015, from http://www.edweek.org/ew/articles/2008/03/27 /30stemtech.h27 .html

[6] Capraro, R. M. \& Corlu, M. S. (2013). Changing views on assessment for STEM project-based learning. In R. M. Capraro, M. M. Capraro, \& J. Morgan (Eds.). STEM project-based learning: An integrated science, technology, engineering, and mathematics (STEM) approach (2nd Edition). (pp. 109-118). Rotterdam, the Netherlands: Sense Publishers.

[7] Ceylan, S. (2014). A study for preparing an instructional design based on science, technology, engineering and math (stem) approach on the topic of acids and bases at secondary school science course, Unpublished master dissertation, Uludag University, Bursa.

[8] Ceylan, S. \& Ozdilek, Z. (2014). Improving a sample lesson plan for secondary science courses within the stem education, Global Conference on Contemporary Issues in Education, GLOBE-EDU 2014, 12-14 July 2014, Las Vegas, USA, Procedia - Social and Behavioral Sciences 177 ( 2015 ) 223 228.

[9] Corlu, M. S. (2014). FeTeMM Eğitimi Makale Cagri Mektubu, Turkish Journal of Education, January, 3(1), 4-10.

[10] Corlu, M.S., Capraro, R.M. \& Corlu, M.A. (2011). Developing algorithmic computations with the help of science: A Turkish middle and high grades study, The Turkish Online Journal of Educational Technology (TOJET), 10 (2), 72-81.

[11] Corlu, M. S., Capparo, R. M. \& Capparo, M. M. (2014).Introducing STEM Education: Implications for Educating Our Teachers for the Age of Innovation, Education and Science, 39 (171), 74-85.

[12] Corlu, M. S., Capparo, R. M. \& Corlu, M.A (2015). Investigating the mental readiness of pre-service teachers for integrated teaching, International Online Journal of Educational Sciences, 2015, 7 (1), 17-28.

[13] Corlu, M. A. \& Corlu, M. S. (2012). Scientific inquiry based professional development models in teacher education. Educational Sciences: Theory \& Practice, 12(1), 514-521.

[14] Corlu, M. S. (2013). Insights into STEM Education Praxis: An Assessment Scheme for Course Syllabi, Educational Sciences: Theory \& Practice, 13(4), 2477-2485.

[15] Daugherty, M. (2013). The prospect of "a" in STEM. Journal of STEM Education, 14(2), 10-15.

[16] Duran M. \& Sendag, S. (2012). A preliminary investigation into critical thinking skills of urban high school students: role of an IT/STEM program, Creative Education, 3(2):241-250.

[17] Hom, E.J. (2014). What is STEM education. Retrieved June 1, 2015, fromhttp://www.livescience.com/43296-what-is-stemeducation.html

[18] Israel, M., Maynard, K. \& Williamson P. (2013). Promoting Literacy- Embedded, Authentic STEM Instruction for Students With Disabilities and Other Struggling Learners. Teaching Exceptional Children, 45 (4), 18-25.

[19] Kuenzi, J. J. (2008). STEM (science, technology, engineering and mathematics) education: Background, federal policy and legislative action. CRS report for Congress. Retrieved June 1, 2015, from http://www.fas.org/sgp/crs/misc/RL33434.pdf

[20] Lantz, H. B. (2009). Science, Technology, Engineering, and Mathematics (STEM) Education: What form? What function? Retrieved June 1, 2015, from http://www.currtechintegration s.com/pdf/STEMEducationArticle.pdf

[21] Marulcu, İ. \& Hobek, K. (2014). Teaching Alternate Energy Sources to $8^{\text {th }}$ Grades Students by Engineering Design Method. Middle Eastern and African Journal of Educational Research, 9, 41-58.

[22] Ministry of National Education (2009). MEB 2010-2014 Stratejik Plani. Ankara, Milli Egitim Bakanligi Strateji Gelistirme Baskanligi. 
[23] NAE \& NRC (National Research Council). (2009). Engineering in $\mathrm{K}-12$ Education: Understanding the Status and Improving the Prospects. L. Katehi, G. Pearson, and M. Feder, eds. Washington, D.C.: The National Academies Press.

[24] National Research Council (NRC). (2010). Exploring the intersection of science education and 21 st century skills: A workshop summary. Washington, DC: National Academies Press.

[25] Reiss, M. \& Holman, J. (2007). S-T-E-M working together for schools and colleges. 1-8, The Royal Society.

[26] Sahin, A., Ayar, M.C. \& Adiguzel, T. (2014). STEM related after-school program activities and associated outcomes on student learning, Educational Sciences: Theory \& Practice, 14(1). doi: 10.12738/estp.2014.1.18763

[27] Salas-Pilco, S.Z. (2013).Evolution of the framework for 21st century competencies. Knowledge Management \& E-Learning: An International Journal (KM\&EL), 5(1), 10-24.

[28] Sanders, M. (2009). STEM, STEM education, STEMmania. The Technology Teacher, 68(4), 20-26.

[29] STEM Education Turkey Report (2015). Gunun Modasi mi? Yoksa Gereksinim mi?

[30] Yamak, H., Bulut, N. \& Dundar, S. (2014). Sinif ogrencilerinin bilimsel surec becerileri ile fene karsi tutumlarina fetemm etkinliklerin etkisi, Gazi Universitesi Egitim Fakultesi Dergisi, 34(2), 249-265. 